\title{
Color vision response to hypoxia at a simulated altitude of 18,000 feet
}

\author{
Corrie Wawolumaya
}

\begin{abstract}
Abstrak
Temuan-temuan penelitian sampai saat ini melaporkan hasil yang belum pasti mengenái pengaruh "altitude hypoxia" terhadap penglihatan warna. Diperlukan penelitian yang bersifat analitik untuk mengkaji secara pasti hubungan tersebut karena penglihatan warna termasuk dalam faktor-faktor kesalahan manusia pada para pilot. Tujuan eksperimen ini untuk membuktikan hubungan kausal antara "altitude hypoxia" dan deviasi penglihatan warna. Telah dilakukan uji klinik acak terhadap kelompok studi dan kontrol yang berasal dari 98 calon penerbang sipil berusia 17-23 tahun. Kelompok studi dipapar pada keadaan "altitude hypoxia" yang setara dengan keadaan hipoksia pada 18.000 kaki, yang dilakukan pada ruang bertekanan udara rendah. Test Ishihara dilakukan pada "ground level" dan keadaan hipoksia 18.000 kaki setelah 6-8 menit, yaitu pada tingkat saturasi $0272-64 \%$. Hasil penelitian membuktikan bahwa pada keadaan hipoksia awal, telah terjadi perpanjangan waktu baca dan penurunan persentase kebenaran membaca lembar Ishihara pada kelompok studi. Perubahan pada kelompok studi berbeda bermakna dibandingkan dengan kelompok kontrol. Penelitian ini menyimpulkan bahwa pada kondisi "altitude hypoxia" awal terjadi perubahan ringan pada penglihatan warna, dan perubahan tersebut masih dalam batas-batas normal.
\end{abstract}

\begin{abstract}
Several studies reported inconclusive results on the influence of altitude hypoxia on color vision. More analytical studies were needed to confirm the relationship, since color vision is one of the important vision parameters contributing to the pilots' human error factors. This experiment aimed to prove the causal relationship between altitude hypoxia at 18,000 feet and color vision changes. A randomized clinical trial using Ishihara book was used to test color vision in the study and control groups. The study and control group was selected randomly among 98 civilian pilot candidates aged 17-23 years. The study group was exposed to altitude hypoxia at 18,000 feet. The Ishihara test was performed at ground level and at 18,000 feet (simulated in a low pressure chamber) after 6-8 minutes, when $72-64 \%$ of $\mathrm{O}_{2}$ saturated blood level was achieved. Results showed that at early hypoxic condition, an increase in total reading time and a decrease in the percentage of plates reading right was identified. The difference was significant between the two groups. This study concluded that altitude hypoxia caused minor changes in color vision at early hypoxic state, which were still in the normal range.
\end{abstract}

Keywords: Ishihara test, low pressure chamber, altitude hypoxia

Color vision is a vital cognitive ability that pilot must preserve to control his aircraft during flight. A disturbed color vision will harm the pilot's space orientation or the three dimentional awareness, which is important for his sense of equilibrium with the surroundings while focusing his eyes straightly at the horizon during the flight. During high altitude flight or during instrument flight at night, pilots must rely the navigation and aircraft control upon their visual ability including color vision. Furthermore, maps reading, instrument data recognition in the cockpit, weather radar interpretation (especially to detect clear

Post Graduate Study for Aerospace Medicine, Department of Community Medicine, Faculty of Medicine, University of Indonesia, Jakarta, Indonesia air turbulence) are some of the applications that need pilot's color vision during flight.

Hypoxia is still a current problem in aviation, although a big progress in aircraft structures has been achieved.

Hypoxia is a condition in which human body experiences shortage of oxygen which affects the funtions of organs. Hypoxia is caused by various factors such as intoxication of organs, vascularization defect, anemic condition, and the decrease of partial pressure of oxygen in the air due to high altitude. ${ }^{1}$

The altitude hypoxia or hypoxic hypoxia might have low oxygen partial pressure, while the blood hemoglobin content is normal. All types of hypoxia could cause serious problems in aviation, and altitude 
hypoxia is the most probable hypoxia happened in aviation. So far, hypoxia occured in aviation did not cause any illness. However there are subjective symptoms observed such as anxiousness, fear, head ache, fatique, vomiting, tunnel vision and euphoria. Still, those symptoms are insidious and varied individually.

Hypoxia has been known to impair almost all kind of visual functions. It is welknown that human brain is not the alarm system for hypoxic condition. The eyes serve as the first organ exposed as well as the most sensitive organ to altitude hypoxia in aviation. Wilmer and Berens as quoted by Richalet et al, in 1920, introduced the role of color vision in aviation. ${ }^{2}$

Kobrick concluded that the sensitivity of color vision to altitude hypoxia was related to the distribution and vascularization of cone cells in retina. The decrease in oxygen supply to the retina and central nerve due to high altitude affects the function and energy spent of cells which are involved in the process of color vision. ${ }^{3}$

However, study results dealing with the effects of altitude hypoxia on color vision are still controversial. Richalet et al, in his study that using a new portable anomaloscope, reported a decrease of green sensitivity which happened at 14,000 feet, but then got normal again after several minutes of adjustment, ${ }^{2}$ while Wilmer and Berens as being quoted by Richalet et.al, at the simulated altitude of 20,000 feet did not report any change in color vision. Sangkalia, in his simulated study with the civilian pilot candidates at $18,000 \mathrm{ft}$, using the Ishihara book test, reported a prolonged total reading time related to altitude hypoxia. ${ }^{4}$ Djunadi, also in a simulated study with Ishihara book test among military pilot candidates, reported a prolonged total reading time at $18,000 \mathrm{ft}(168$ seconds) compared to 136 seconds in ground level, ${ }^{5}$ but both Sangkalia and Djunadi failed to prove the causality between color vision deviation and hypoxia, since the multivariate analysis did not prove blood oxygen saturation level as a determinant of changes in color vision.

This study aims to prove the causal relation between altitude hypoxia at $18,000 \mathrm{ft}(\mathrm{Fl} \mathrm{180})$ and color vision defects.

\section{METHODS}

The study was conducted at the Indonesian Center for Aerospace Medicine Saryanto, Jakarta (Lakespra) which belonged to the Indonesian Airforce. The laboratory is equipped with the hypobaric chamber, night vision trainer etc.

The equipments used were the hypobaric chamber (Environ. Tectonic Corp. USA, 1981), pulse oxymeter (type SaO2-5000, Med. System Co, serial no 9111656, USA), stopwatch and luxmeter (type ANAF9 no 941942, Tokyo Photo-Electric Co-Ltd, Japan).

The study design is a single blinded randomized clinical trial. The recruitment of subjects was conducted in Lakespra, where the pilot candidates came for pilot standard medical examination and aerophysiology training. Using the sample size formula for clinical trial (with level of significancy of $5 \%$ and test power of $80 \%$ ), the sample size calculated will be $n 1=n 2=20$ subjects. ${ }^{6}$ However, taking only 20 subjects from the whole batch of the civilian pilot candidates is not allowed by Lakespra. Therefore, all subjects of the whole batch which met the inclusion and exclusion criterias were taken as a total sample of 98 subjects. The subjects were divided into two groups, the study and the control group, which were selected randomly. The inclusion criteria for the study and control group were man, aged 17-23 years, has passed the sinus check at the altitude of $5000 \mathrm{ft}$, willingly to sign the informed consent and has passed the pilot standard medical examination. The examination included the lung function and eye refraction test, and is acknowledged matching the first class passing criteria of the International standard of Civil Aviation Organization (ICAO).

The study group was subjected to simulated flight to produce altitude hypoxia at FL 180 using the hypobaric or the low pressure chamber, while the control group did not experience hypoxia.

All subjects from the study group used pure $\mathrm{O} 2$ mask while flying to FL 180 . At FL 180, after releasing the O2 mask, the percentage of blood saturated oxygen (SaO2) was measured. The $\mathrm{O} 2$ mask was released, and at the hypoxic condition, the measurements (Ishihara test and pulse rate) was conducted. The illumination used in reading both in ground level and FL 180 were between 300-400 lux. The hypoxic condition at $\mathrm{FL} 180$ was defined by the range of $\mathrm{SaO} 2$ between $72 \%-64 \%$.

This study used Ishihara book test to identify color vision change due to altitude hypoxia at FL 180. 
Ishihara book is a tool for color vision test that consists of pages with colored spots. Through daylight or appropriate artificial lighting the colored spots will produre a light spectrum reflecting the sensitivity of the retina cone cells. The Ishihara book used consists of 38 plates. $^{7}$

The variables were measured at ground level (GL) and FL 180. The dependent variables were the operational variables of color vision :

1. plates reading time (TPRT) in second (plate 1-25, normal reading time $\leq 3$ seconds each plate, and the interpretation of plate $26-38 \leq 10$ seconds each plate. So, the normal total reading and interpretation time of the whole plates i.e. plate 138 is $\leq 205$ seconds).

2. right reading of number of plates (RRNP) (the percentage of plates (no. 1-21) which are right read.

The normal color vision, or red - green deficiency was concluded if the subject can read rightly $\geq 17$ plates $(\geq$ $80.95 \%)$, or $\leq 13$ plates $(\leq 60.19 \%)$ respectively. The latter was grouped in the form of protan or deutan through the reading of plate no. 22-25.

The independent variables measured at ground level and FL 180 were the percentage of blood saturated $\mathrm{O} 2$ ( $\mathrm{SaO} 2)$ and pulse rate.

The other related independent variables only measured at GL were blood hemoglobin content $(\mathrm{Hb})$, sistolic and diastolic pressure. The elapse time from releasing the oxygen mask until changes in measurements occurred was noted.

Statistical analysis was done to identify the difference in independent variables between the study and control group, at the admission stage (GL) and FL 180.

\section{RESULTS}

At the admission stage (GL), the variables measured in the study and control group is presented in Table 1. Using independent $\mathrm{t}$-test, there were no significant difference $(P>.05)$ identified in $\mathrm{Hb}$, sistolic and diastolic pressure, SaO2, TPRT and RRNP, except pulse rate, between study and control group (Table 1).
Table 1. The variables of the study and control group at GL

\begin{tabular}{lrrrrl}
\hline Variables & \multicolumn{2}{c}{ Study $(\mathrm{n}=49)$} & \multicolumn{2}{c}{ Control $(\mathrm{n}=49)$} & $P$ \\
& Mean & SD & Mean & SD & $(.05)$ \\
\hline 1. Hb & 15.2 & 0.8 & 15.2 & 0.9 & 0.95 \\
2. Sistolic & 121.2 & 8.3 & 122.7 & 7.9 & 0.30 \\
3. Diastolic & 96.9 & 5.2 & 78.0 & 5.0 & 0.23 \\
4. SaO2 & 96.9 & 2.2 & 96.6 & 2.6 & 0.65 \\
5. Pulse Rate & 91.6 & 13.8 & 98.5 & 14.0 & $0.01^{* *}$ \\
6. TPRT & 56.6 & 9.8 & 56.1 & 8.3 & 0.81 \\
7. RRNP & 98.3 & 2.4 & 98.8 & 2.2 & 0.27 \\
\hline
\end{tabular}

$P=$ probability of significant difference between the study and control group

** highly significant

$\mathrm{SD}=$ standard deviation

Table 2 shows the study and analyses results i.e., $\mathrm{SaO} 2$, pulse rate and color vision (TPRT \& RRNP), and $P$ of the difference between the study and control group at FL 180. Since the control group did not experience hypoxia, the control group was examined twice, firstly at the same time with the study group at GL before the study group being subjected to hypoxia, and secondly after the study group has experienced hypoxia at FL 180.

There were significant differences $(P<.05)$ identified in $\mathrm{SaO} 2$, pulse rate, TPRT and RRNP, between the study and control group, at FL 180. In the study group, at FL 180, no subjective symptoms or euphoria was observed. The average elapse time from releasing the oxygen mask until the changes in color vision occurred ranged from 6-8 minutes.

Table 2. The SaO2, pulse rate, TPRT, and RRNP of the study and control group at FL 180, and analyses results

\begin{tabular}{|c|c|c|c|c|c|}
\hline \multirow[t]{2}{*}{ Variables } & \multicolumn{2}{|c|}{ Study $(n=49)$} & \multicolumn{2}{|c|}{ Control $(n=49)$} & \multirow[t]{2}{*}{$P$} \\
\hline & Mean & SD & Mean & $\mathrm{SD}$ & \\
\hline 1. $\mathrm{SaO} 2$ & 68.2 & 2.9 & 96.7 & 2.6 & 0.000 ** \\
\hline 2. Pulse Rate & 115.3 & 11.7 & 98.7 & 14.0 & $0.000 * *$ \\
\hline 3. TPRT & 72.1 & 17.3 & 56.0 & 8.3 & $0.000 * *$ \\
\hline 4. RRNP & 97.5 & 3.4 & 98.7 & 2.2 & $0.032 *$ \\
\hline
\end{tabular}

$P=$ probability of significant difference between the study and control group

* significant

** highly significant

\section{DISCUSSIONS}

Statistical analyses of the admission variables at GL, showed that there were no significant difference in all 
variables except pulse rate, between the study and control group (Table 1). The pulse rate difference could be due to psychological factor, such as the subjects anxiety of what were going to happen to them since the measurements were conducted at the chamber.

$\mathrm{Hb}$, systolic and diastolic blood pressure were not measured in FL 180, as it was difficult to conduct the measurements in the chamber. Furthermore, all were assumed not to be changed. $\mathrm{Hb}$ would change if bleeding happened, and blood pressure was not altered by high altitude. ${ }^{1}$ So, at FL 180 , the statistical analyses was carried out only on four variables measured i.e., $\mathrm{SaO} 2$, pulse rate, TPRT and RRNP.

At FL 180, statistical analysis of all four variables, $\mathrm{SaO} 2$, pulse rate, total plates reading time (TPRT) and right reading number of plates (RRNP) showed significant difference between the study and control group. These results revealed that at FL 180 significant changes happened in those four variables of the study group compared to the control group (at GL). In the study group, the percentage of blood saturated oxygen (SaO2) was decreasing from $96.9 \%$ to $68.2 \%$. This fact showed the hypoxic condition at FL 180. The pulse rate was increased from 91.6 to 115.3 , TPRT was prolonged from $56.6 \mathrm{sec}$. to 72.1 sec. and RRNP was decreased from $98.3 \%$ to $97.5 \%$.

However, the measurements of color vision parameters at GL in both study and control groups did not show any deviation from the the normal value. The TPRT is the time used to read and to interprete the Ishihara pages from $1-38$. The normal TPRT is about less or equal to 205 seconds. Therefore, the significant increase of TPRT at FL 180 is still in the normal range.

The decrease of RRNP to $97.5 \%$ in the study group, which showed a significant difference $(P=.03)$ compared to the control group (98.7\%), meant a decrease in RRNP was occurred, but still in the normal range.

The altitude hypoxia based on atmospheric pressure, altitude and blood oxygen pressure could be differentiated in several stages. ${ }^{8}$ The indifferent stage occurs at $0-10,000$ feet. In this stage, prolonged dark adaptation happened. The compensatory stage occurs at $10,000-15,000 \mathrm{ft}$, and shows no signs of hypoxia due to physiologic body compensation. However, in case of prolonged condition or doing some physical activities, hyperventilation, accelerated pulse rate might be observed. The disturbance stage occurs at $15,000-20,000 \mathrm{ft}$. At this stage no physiologic body compensation for oxygen happens, therefore symptoms scuh as fatique, laziness, sleepy, dizzy, headache, and euphoria can happen. The critical stage occurs at $20,000-23,000 \mathrm{ft}$, and causes lost of consciousness which happens very soon.

The altitude hypoxia at $18,000 \mathrm{ft}$ is a disturbance stage of hypoxia with no physiological body compensation, thus the objective as well as subjective symptoms can happen such as pulse rate increase, fatigue, dizziness, euphoria etc. The major reason of using the simulated altitude of 18,000 feet was that at this altitude the time use of consciousness (TUC) was between 20-30 minutes. Therefore, the subjects were still conscious, and cooperative while the study was conducted. FL 180 is also the cruising altitude of the Indonesian pilots. In this experiment measurements were conducted as soon as $\mathrm{SaO} 2$ reached the range between $72 \%-64 \%$ which is the early stage of hypoxia, when the TUC was about 30 minutes. Nevertheless, early minor changes in color vision has occured.

The perception of color vision involved three main factors. The physical factor which is the light stimulation accepted by retina. The physiologic factor involving the photochemical reaction of retina light cell receptors, the process at the nerve system, and the vascularization of retina. The third factor is the color perception seen by somebody. The pathological changes which could disturb color perception might happen at visual pigments, the receptor process or at the process of transmission of eye optical tools. It is very seldom that color vision is affected by cortical cerebral lesion. Color vision deviation could also due to genetic defect. ${ }^{9}$

In this study, minor changes in color vision might be due to the effect of early hypoxia which disturbed the retinal vascularization, especially the cone cells. The blood supply was still enough but the $\mathrm{SaO} 2$ decreased and resulted in disturbance of color vision process. ${ }^{3}$

At FL 180, RRNP results showed no red-green deficiency, neither protan, nor deutan. Green sensitivity deficiency such as mentioned by Richalet was identified at $14,000 \mathrm{ft}$. This could be due to the difference in the equipment used. Richalet used anomaloscope which is more sensitive compared to Ishihara test. ${ }^{2}$ Sangkalia and Djunadi both used a pre- 
post test design without control. They reported that color vision was affected by hypoxic condition at FL 180 , in which prolonged total plates reading time and decrease in the percentage of plates reading right was identified. However, both studies using the multivariate analyses failed to prove that the percentage of blood saturated oxygen at $18,000 \mathrm{ft}$ or the hypoxic condition was a determinant of color vision changes. ${ }^{4,5}$

The average elapse time from releasing the oxygen mask until the changes in color vision occured ranged from 6-8 minutes. The time of useful consciousness at 18,000 feet is about 30 minutes, and the subjects will lose his awareness after 30 minutes exposed to altitude hypoxia. These facts revealed that the changes in color vision found in this study were still in the normal range and accounted to the early sign of hypoxia at $18,000 \mathrm{ft}$.

\section{CONCLUSIONS}

The altitude hypoxia at $18,000 \mathrm{ft}$ caused color vision minor changes, i.e. prolonged plates reading time and decrease of percentage of plates reading right, both were still in the normal range of color vision. No protan and deutan occured. At 18,000 feet the elapse time of hypoxia ranged between 6-8 minutes, which was still accounted as the early stage of hypoxia. Thus, among civilian pilot candidates, color vision minor changes caused by altitude hypoxia were the early sign of hypoxia at $18,000 \mathrm{ft}$.

\section{SUGGESTION}

Altitude hypoxia is still a problem in aviation due to its characteristics which happen insidiously and the symptoms vary individually. Pilots in hypoxic condition does not realize the problem, and after several minutes he will get euphoria which is one of the major aircraft disaster. This study findings could be used as a measure to detect early hypoxia at 18,000 $\mathrm{ft}$. Combining with other visual parameters which are affected by altitude hypoxia very early, this study result could be used to develop an artificial intelligence (AI) for the safety of the pilots.
The artificial intelligence will adopt the affected visual parameter values through evoked potentials, change it into electromagnetic waves, and then connected it to an alarm system.

\section{Acknowledgments}

The author would like to thank Drs.Imam Soekoesno, Medical Aviation Specialist, and Sumardoko, opthalmologist, both in Lakespra, for their assistance in the aviation and opthalmologic substances in this article. Also to Drs Djunadi \& Felix, who assisted me to collect data from the chamber in Lakespra. My appreciation to the Center for Medical Aerospace Saryanto, Indonesia (Lakespra) for facilitating this project. I am especially grateful to all the subjects who took part in this study.

\section{REFERENCES}

1. Dhenin G. Aviation medicine physiology and human factor. London: Tri Med Books; 1978. p. 61-81.

2. Richalet JP, Amould GD, Amaud B, Keromes A, Rudgers V. Modification of color vision in the green/red axis in acute and chronic hypoxia explored with a new portable anomaloscope. Aviat Space Environ Med 1988;59: 620-3.

3. Kobrick J. Progressive effects of hypoxia on cognition and symptomatology. 38 th International Congress of Aviation Medicine; 1990 Sep 10-13: Paris, France.

4. Sangkalia F. A study on the relation between color vision and altitude hypoxia $180.000 \mathrm{ft}$ among civilian pilot candidates. [thesis]. Jakarta: Univ of Indonesia; 1996.

5. Djunadi. A study on the realtion between color vision and altitude hypoxia at $180.000 \mathrm{ft}$ among military pilot candidates Jakarta. [thesis]. Jakarta: Univ of Indonesia; 1998.

6. Wawolumaya C. Experiment, the epidemiologic method. Jakarta: Setia Bumi Jaya; 1997.

7. Ishihara S. The series of plates designed as a test for color blindness. 38 plates edition. Japan: Kanehara Shuppan; 1980.

8. The Directorate of Health of the Indonesian Air Force. The book of principles of aviation medicine. Jakarta: The Directorate of Health of the Indonesian Air Force; 1991. p. 25-53.

9. Birch J. Diagnosis of defective colour vision. New York: Oxford Univ Press; 1993. 